O-143孤発性蝶形骨洞真菌症の診断における内視鏡検 査の有用性について

○秋山 貢佐, 米崎 雅史, 星川 広史

香川大学医学部耳鼻咽喉科・頭頸部外科

はじめに：孤発性蝶形骨洞病変 (ISSD) は全副鼻腔 病変のうち $1-3 \%$ 程度とされ，比較的まれな疾患であ る。そのうち真菌症は約 $20 \%$ 程度を占めると考えられて いる。孤発性蝶形骨洞真菌症; isolated sphenoid sinus aspergilloma（ISSA）は無症候性のことも多いが解剖学 的な問題から時に頭蓋内, 眼窩などに重篤な合併症を生 じることもある。診断はCT, MRI, 内視鏡などによる が症例によっては術前診断が困難である場合もある。 我々は $2.2 \mathrm{~mm}$ の細径フレキシブルファイバーを用いて 蝶形骨洞を観察し外来での診断に役立ておりその有用性 について報告する。方法：2013年-2016年に三豊総合病 院および香川大学医学部附属病院耳鼻咽喉科を受診し た, ISSD症例は28例であり, そのうち病理診断, 細菌 検査にてアスペルギルスの存在が確認され, ISSAと最 終的に診断した15例を対象にレトロスペクティブに検討 を行った。結果：無症状で偶然発見されたものが7例で 最多であった。初診時のCTで明らかな石灰化像は8例に 確認できた。内視鏡検査にて蝶形骨洞内を確認でき, 真 菌塊を明視下に確認できたものが7例 $(46.7 \%)$, 洞内の 観察不可で蝶篩陥凹にも所見を認めないものが6例で あった。MRIを追加した症例は5例あったが，そのうち4 例では特徴的な所見は得られなかった。手術不能であっ た1例を除いた14例でESSを施行した。まとめ：ISSAに おいて内視鏡検査の大半は異常所見を認めず, 術前診察 における有用性はないものと報告されている。今回我々 は独自の工夫を施した内視鏡検査を術前に行い，60\%に 何らかの異常所見を確認可能であった。さらに7例では 直接的な真菌塊の確認による診断が可能であった。これ までの概念を覆す高い有用性が確認でき, ISSAに対し てはルーティンとして行うべき検査であると考えられた。
O-144 特殊なOnodi cellと蝶形骨洞 (CLS, CLE) の 検討一蝶形骨洞の解剖学的分類に基づいて一

○武田 鉄平 ${ }^{1}$, 新井 千昭 ${ }^{1}$, 長舩 大士 ${ }^{1}$, 柳清 ${ }^{2}$, 和田 弘太 ${ }^{1}$

${ }^{1}$ 東邦大学医療センター大森病院耳鼻咽喉科 聖路加国際病院耳鼻咽喉科

前頭洞はWormaldが提唱した解剖学的な分類により, 安全かつ確実な開放が行われるようになった。一方，蝶 形骨洞の分類には明確なものがなく，下垂体手術に用い られる分類しかなかった。ESSにおける蝶形骨洞の同定 の難しさには, Onodi cellの存在と蝶形骨洞の中隔の傾 きにあると思われる。2015年に柳, 和田らは矢状断CT を用いて視神経管に注目することでOnodi cell, 蝶形骨 洞前壁の形態をSkull base type, Optic type, Sella type, Infra-sella typeに分類する方法を提唱した。この分類に よって，最後部篩骨洞が蝶形骨洞の上側方に発育する Onodi cellの程度を同定し，蝶形骨洞の開放方法を術前 に予測できるとした。しかしこの方法で分類しにくい Onodi cell, 蝶形骨洞の形態がある。それは一側蝶形骨洞 が対側の蝶形骨洞に覆いかぶさるContra-lateral sphenoid sinus（CLS）や片側のOnodi cellが対側の蝶形骨洞に乗 り上げるContra-lateral ethmoidal Onodi cell (CLE) と 思われる。このCLEは一側のOnodi cellに両側の視神経 が走行する。これらの形態を術前に認識することで, より安全な手術操作につながると考えられる。今回わ れわれは，2015年1月から12月までに当院で施行した 副鼻腔手術症例219例（438側）において術前CTを retrospectiveに見直し, Contra-lateral sphenoid sinus (CLS), Contra-lateral ethmoidal Onodi cell (CLE) の 存在率を調べたためここに報告する。またそれらの確認 方法を報告する。 
O-145 術中に同定されるOnodi cell, 蝶形骨洞内にお ける内頸動脈, OCRについて

○梶原 理子, 新井 千昭, 武田 鉄平, 長船 大士, 和田 弘太

東邦大学医療センター大森病院耳鼻咽喉科

内視鏡下鼻副鼻腔手術（以下ESS）は慢性副鼻腔炎や 様々な副鼻腔疾患に対して行う手術としてスタンダード である。ESSを合併症なく安全に行うためには, 副鼻腔 内だけでなく副鼻腔外の解剖を知ることが重要である。 我々が注目したいのは内頸動脈の走行である。内頸動脈 は, 頸部を上行し錐体部で内側に移動し, 再度, 蝶形骨 洞後壁を上行する。その後, 前方に移動し後方にターン し視神経の下方を走行し（C4-C2 portion），ウイリス動 脈輪へ入る。頭蓋底手術を施行されている方は十分に注 意をされていると思うが，副鼻腔手術を主に施行してい る我々は，この部位にはあまり注意をしてこなかったの ではと考える。蝶形洞の開放についてのコンセプトは和 田らが報告するまではなかったが，我々はこの蝶形洞分 類を用い, 術前にCT画像からタイプ分けをして蝶形洞 の評価をしている。このタイプ分けにより, Onodi cell, 蝶形洞の開放イメージができるようになり安全, 正確に 手術が行えるようになった。今回はOnodi cell, 蝶形骨 洞の開放を安全に行うために, 重要構造である視神経, 内頸動脈, OCR (Optico-carotid recess) に着目し術中 にこれらが同定できるか検討したので報告する。

\section{O-146 前頭洞排泄路と前頭洞炎の画像的評価}

○橋本 健吾, 都築 建三, 岡崎 健, 阪上 雅史 兵庫医科大学耳鼻咽喉科・頭頸部外科

\section{【はじめに】}

前頭洞の処理は頭蓋底, 眼窩, 前篩骨動脈など解剖学 的および斜視鏡操作など技術的な面からしばしば困難を 伴う。より安全に内視鏡下鼻・副鼻腔手術を行うために, 鼻副鼻腔の基本解剖の習熟が必要である。前頭洞排泄路 について画像的に評価し，篩骨蜂巣群と前頭洞の炎症の 関係について検討した。

【対象と方法】

2015年4月から2016年3月の12か月に当科で鼻・副鼻腔 初回手術を施行し, 術前の副鼻腔CTで3方向（軸位・冠 状・矢状断)で評価しえた93例186側を対象とした。腫瘍, 外傷, 鼻手術既往例は除いた。男性64例，女性29例。平 均年齢48.5歳（13-83歳）。Kuhnらの前頭陥凹セルの分類 に準じ, agger nasi cell (ANC), frontal ethmoidal cell (FEC), ethmoid bulla (EB), suprabullar cell (SBC), frontal bulla cell (FBC) について, 各蜂巣の存在率を 評価し，前頭洞炎との関係について評価した。また前頭 洞排泄路（frontal ostium, FO）の径は, nasofrontal beakから前頭蓋底へ垂直にひいた直線の最短距離 $(\mathrm{mm})$ で評価した。

\section{【結果】}

各蜂巣の存在率はANC 184/186側（99\%）, FEC 71/186 側 (38\%), EB 186/186側 (100\%), SBC 128/186側 (69\%), FBC 29/186側（16\%）であった。各蜂巣の存在と前頭 洞の炎症に有意に関連は認めなかった。各蜂巣の混濁像 と前頭洞炎との関係については, ANC, T1, EB, SBC に有意な関連を認めた。非好酸球性副鼻腔炎に限った検 討では, ANC, T1, EBに有意な関連を認めた。FOと 前頭洞の炎症との関係について, 前頭洞炎のある群（FO $8.31 \pm 2.22 \mathrm{~mm})$ とない群（FO $8.29 \pm 2.55 \mathrm{~mm} ）$ に有意差 は認めなかった。

\section{【考察】}

各蜂巣の存在と前頭洞炎とは関連を認めなかった。 $\mathrm{ANC} \cdot \mathrm{T} 1 \cdot \mathrm{EB} \cdot \mathrm{SBC}$ における炎症が，有意に前頭洞炎 と関連していた。FOは, 前頭洞炎と有意な関連はなかっ た。前頭洞排泄路の画像的評価は術前のプランニング, 術者のスキルアップ，チーム間での共通理解に有用で あった。 
O-147 いわゆる “鈎状突起上方付着部”の分類に関す る考察

$\bigcirc$ 月舘 利治 $^{1}$, 石井 正則 $^{1}$, 浅香 大也 ${ }^{2}$, 小島 博已 ${ }^{2}$, 鴻信義 ${ }^{2}$

${ }^{1} \mathrm{JCHO}$ 東京新宿メディカルセンター耳鼻咽喉科 ${ }^{2}$ 東京慈恵会医科大学耳鼻咽喉科

Stammbergerは鈎状突起の上方付着部を眼窩内側壁, 頭蓋底, 中鼻甲介の3型に分類しており, さらに Landsbergらはこれを基に6型に分類している。これら の分類は2014年のRhinologyのterminologyに関する position paperにも記載され認知されており，また，非 常に単純化されているので実際に冠状断CT画像を眺め てみると一見わかりやすく思える。しかし，その情報を 基に鈎状突起，前頭窩を頭のなかで立体映像として再構 築する際に違和感を感じることがあり，また，実際の前 頭洞開放にあたっては, Building block conceptのよう な有用性が感じられない。この理由として, 以下の2つ が挙げられる。まず, “鈎状突起の上方付着部”という 定義自体が不適切ではないかと考える。鈎状突起は篩骨 の一部で, 矢状断では前上方から後下方に走る薄い鎌状 の構造物なので, 上方で眼窩内側壁や頭蓋底に付着する という定義が分かり難い。次に, これらの分類がCT画 像のうち冠状断のしかも数スライスのみで分類している ため, 実際の手術に必要である3Dの情報は得にくく2D の情報となってしまうことが挙げられる。しかし， CT 冠状断画像を用いた分類方法そのものは, 単純かつ簡素 化されており，受け入られやすいと思われるので，分類 の解釈・解説を新たに与えれば, 前頭窩手術においてよ り有用となる可能性がある。今回我々は, 3D医用画像 処理ソフトウェアを用いてCT画像を検討した。その結 果, “鈎状突起上方付着部”としているのは, 実際には “frontal recessを構成するcellの隔壁（主に内側壁）の 走行”を見ていることがわかった。また, CD画像の1ス ライスの見え方で分類するのではなく, 数スライスの所 見で分類することにより3D情報となり，実際の手術に 有用なデータになると考えた。

\section{O-148 鼻腔に発生した毛包腫例}

○屋 洋省 ${ }^{1}$, 生駒 亮 ${ }^{1}$, 和田 昂 ${ }^{1}$, 高畑 喜延 ${ }^{2}$, 折舘 伸彦

${ }^{1}$ 国家公務員共済組合連合会横浜南共済病院耳鼻咽喉科 2 高畑耳鼻咽喉科医院

${ }^{3}$ 横浜市立大学附属病院耳鼻咽喉科・頭頸部外科

毛包腫（trichofolliculoma）は，顔面に好発する，毛 包の索状上皮及びその周囲に存在する結合織に由来する 良性腫瘍である。症例は54歳男性, 主訴は左鼻腔腫瘤に よる左鼻閉。現病歴は5年前から左鼻腔入口部に腫瘤を 自覚。徐々に増大するため, 近医受診し, 当科紹介となっ た。現症では左鼻翼の鼻腔側に基部を持つ有茎性，弾性 硬の径 $15 \mathrm{~mm}$ 程度の腫瘤を認めた。圧痛や择痒感はなく, 分泌物も認められなかった。CT, MRIでは同部位に $15 \mathrm{~mm}$ 程度の隆起性病変を認め, 線維性成分を含む腫瘍 性病変が疑われた。局所所見および発育が緩やかで積極 的に悪性腫瘍は疑わず，術前の生検なしに全身麻酔下で の腫瘤摘出術を行う方針とした。術中所見では，左鼻腔 の皮膚粘膜移行部付近に腫瘤の基部を認めた。腫瘤は皮 下直下に存在し，左大鼻翼軟骨と接していたが癒着はな く, 鈍的剥離が可能であった。腫瘤表面の皮膚を一部合 併切除した。病理所見では, 皮膚表面から深く陥入した, 角質や毛髪片を入れ，表皮洞の周りに毛包分化構造物を 認める毛包系腫瘤で, 病理診断は毛包腫であった。毛包 腫は皮膚科領域での報告は散見するが，耳鼻咽喉科領域 での報告は少なく, 鼻腔発生の毛包腫は極めて稀である。 本症例について報告する。 